\title{
Агробиологическая оценка перспективных белоягодных сортов винограда в условиях Анапо-Таманской зоны Краснодарского края
}

\author{
Леонид Петрович Трошин ${ }^{1}$, д-р биол. наук, професcop, lptroshin@mail.ru; \\ Роман Викторович Кравченко ${ }^{1}$, д-р с.-х. наук, доцент; \\ Николай Васильевич Матузок ${ }^{1}$, д-р с.-х. наук, профессор; \\ Пётр Пантелеевич Радчевский ${ }^{1}$, канд. с-х. наук, доцент, radchevskii@rambler.ru \\ Горлов Сергей Михайлович ${ }^{2}$, канд. техн. наук, доцент \\ ${ }^{1}$ Кубанский государственный аграрный университет, 350044, Россия, Краснодарский край, Краснодар, Калинина, 13 \\ ${ }_{2}^{2}$ «раснодарский научно-исследовательский институт хранения и переработки сельскохозяйственной продукции» - филиал ФГБНу \\ «Северо-Кавказский федеральный научный центр садоводства, виноградарства, виноделия» Краснодарский край, г. Краснодар, \\ ул.Тополиная аллея, 2
}

В статье дан обзор результатов агробиологической оценки перспективных белоягодных сортов Йоханнитер и Солярис, а также клонов винограда Анри К и Сенной К в условиях Анапо-Таманской зоны Краснодарского края. Технология возделывания винограда на опытном участке соответствовала принятой для данной зоны и культуры. Агробиологические работы проводились в оптимальные сроки и отличались высоким качеством исполнения. Кусты винограда заложены по схеме 3,0 х 2,0 м. Формировка - двуплечий горизонтальный кордон. На кустах формировалась одинаковая нагрузка побегами и гроздями. Анализ экспрессивности фенотипических количественных признаков и свойств, то есть агробиологических и хозяйственно-технологических показателей, изучаемых сортов и клонов винограда свидетельствует о том, что почвенно-климатические условия Темрюкского района оказались благоприятными для их возделывания. При этом для сорта Йоханнитер и его клона Анри К характерен ранний срок созревания, а для сорта Солярис, его клона Сенной К и сорта Екатеринодарский - средне-ранний. Суммирование рангов сортов по признакам позволяет классифицировать их по комплексной ценности (в убываюшем порядке): Екатеринодарский, Йоханитер, Анри $\mathrm{K}$, Солярис, Сенно К. Анализ результатов исследований показал, что новые интродуцированные сорта и созданные на их основе клоны винограда, выделившиеся по признаку стабильной и высокой урожайности (Анри К и Йоханнитер), а также высокого качества (Сенной К и Солярис), возможно рекомендовать для промышленного возделывания на виноградниках Анапо-Таманской зоны Краснодарского края.

Ключевые слова: виноград; сорта Йоханитер и Солярис; клоны Анри К и Сенно K; увологическая и комплексная оценка; урожайность.

\section{Как цитировать эту статью:}

Трошин Л.П., Кравченко Р.В., Матузок Н.В., Радчевский П.П. Агробиологическая оценка перспективных белоягодных сортов винограда в условиях Анапо-Таманской зоны Краснодарского края // «Магарач». Виноградарство и виноделие, 2019; 21(2). C. 102-104. DOI 10.35547/IM.2019.21.2.004

How to cite this article:

Troshin L.P., Kravchenko R.V., Matusak N.V., Radchevsky P.P. Agrobiological assessment of promising white-berry grapevine cultivars in the conditions of the Anapa-Taman zone of the Krasnodar Krai. Magarach. Viticulture and Winemaking. 2019; 21(2); pp 102-104. DOI 10.35547/IM.2019.21.2.004

удК 634.863:631.524.5/.8(470.62)

Поступила 19.12.2018

Принята к публикации 16.05.2019

(c) Авторы, 2019
O R I G I N A L A R T I C L E

\section{Agrobiological assessment of promising white-berry grapevine cultivars in the conditions of the Anapa-Taman zone of the Krasnodar Krai}

Leonid Petrovich Troshin ${ }^{1}$, Roman Viktorovich Kravchenko${ }^{1}$, Nikolai Vasilevich Matusak ${ }^{1}$, Peter Panteleevich Radchevsky ${ }^{1}$, Sergey Mikhailovich Gorlov ${ }^{2}$

${ }^{1}$ Kuban State Agrarian University, 13 Kalinina Str., 350044, the Krasnodar Krai, Russia

${ }^{2}$ «Krasnodar Research Institute of Agricultural Products Storage and Processing» - branch of FSBSO "North-Caucasian Federal Scientific Center of Horticulture \&

Viniculture»

The article gives an overview of the agrobiological assessment findings on promising white-berry cultivars 'Johanniter' and 'Solyaris', and clones of 'Anri K' and 'Sennoi $\mathrm{K}$ ' vines under the conditions of the Anapa-Taman zone of the Krasnodar Krai. The cultivation technology used at the experimental plot was consistent with the standard one for this zone. The agro-biological works were carried out within an optimum time frame, and were of a high quality. Vine bushes were planted following the pattern of $3.0 \times 2.0 \mathrm{~m}$., and were trained as winged arbor. The vine bushes had equal shoot and bunch load. Phenotypic quantitative traits and properties expression profiling (agro-biological, economic and technological data analysis) of the studied cultivars and clones confirmed suitability of the soil and climatic conditions of the Temryuk region for their cultivation. 'Johanniter' and its clone 'Anri K' were characterized by an early ripening period, while cultivar 'Solyaris', its clone 'Sennoi K' and 'Yekaterinodar' cultivar were medium-early. Summing up grades of the cultivars by their traits helps rank them by their complex value (in descending order): Yekaterinodar', 'Johanniter', 'Anri K', 'Solyaris', 'Sennoi K'. Data analysis suggests that the new introduced cultivars and their clones demonstrating high yields ('Anri K' and 'Johanniter') and high quality ('Sennoi K' and 'Solyaris') can be recommend for industrial cultivation in the vineyards of the Anapa-Taman zone of the Krasnodar Krai.

Keywords: grapes, vines, cultivars 'Johanniter' and 'Solyaris', clones 'Anri K' and 'Sennoi K', uvologic and complex assessment, yielding capacity

$\mathrm{B}$ настоящее время возросла потребность в пополнении сортимента винограда аАаптивными, ценными по агробиологическим и технологическим свойствам, конкурентоспособными сортами и клонами, внеАрение в производство которых обеспечит повышение рентабельности виноградовинодельческой отрасли [4, $6,9]$.

Почвенно-кииматические условия Краснодарского края, основного региона виноградовинодельческой продукции РФ позволяют возделывать сорта разных направлений использования и различных сроков созревания. Анализ сортимента виноградных насаждений в регионе показывает, что он искиючительно разнообразен, однако отдельные группы сортов, востребованные производством, преАставлены недостаточно. В настоящее время возросла потребность в пополнении сортимента винограда адаптивными, ценными по агробиологическим и технологическим свойствам, конкурентоспособными сортами и көонами, внеАрение в производство которых обеспечит повышение рентабельности виноградовинодельческой отрасли $[3,7,8]$.

Но, как известно, сорт только тогАа в максимацьной степени про- 
явцяет свои потенциацьные возможности, когда условия, в которых он возделывается, в максимацьной степени отвечают его биомогическим особенностям $[1,2,10]$.

Целью наших исследований явимось фенотипирование, то есть изучение хозяйственно-биологических и технологических особенностей новых интродуцированных сортов и кмонов винограда технического направления испо ьзования и выделение наиболее ценных из них аля Анапо-Таманской зоны виноградарства Краснодарского края.

Объекты исследования: перспективные белоягодные сорта Йоханнитер и Сомярис, а также кмоны винограда Анри К и Сенной К. Контролем служиц сорт Екатеринодарский.

Исследования проводились в соответствии с тематическим планом научных исследования кафедры виноградарства Кубанского государственного аграрного университета и явились продолжением ранее начатых исследований [5]. Агротехника общепринятая А я Аанной зоны и культуры. Агробиологические работы проводимись, в оптимацьные сроки и отличацись высоким качеством исполнения. Кусты винограда заможены по схеме 3,0 х 2,5 м. Формировка высокоштамбовый Авупмечий горизонтацьный корАон. Все агробиологические учеты проводицись по общепринятым методикам.

Анализ экспрессивности фенотипических количественных признаков и свойств, то есть агробиологических и хозяйственнотехнологических показателей, изучаемых сортов и кцонов винограда свидетельствует о том, что почвенно-кмиматические условия Темрюкского района оказались благоприятными Аһя их возАемывания. При этом Аһя сорта Йоханнитер и его кмона Анри К характерен ранний срок созревания, а Аля сорта Сомярис, его кмона Сенной К и сорта Екатеринодарский - среАне-ранний.

В годы исслеАований сорта интродуценты немецкой селекции Иоханнитер и Солярис в условиях неукрывной зоны виноградарства Краснодарского края имели

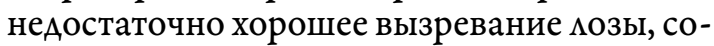
ответственно, 76 и 77\%. В то же время кмоны (Сенно К и Анри К), полученные на их основе и отобранные в условиях Анапо-Таманской зоны, имели уже хороший процент вызревания мозы - 82 и $83 \%$, что сопоставимо с контроцьными показателями сорта Екатеринодарский - $84 \%$.

Наибольшая сила однолетнего прироста отмечена у кмона Анри К (73,1 м на куст) и сорта Йоханнитер (71,0 м на куст). По Алине побега все сорта кмассифицирова$\Lambda$ ись как симьнорослые.

У изучаемых сортов и кмонов винограда
Таблица 1. Сравнительная биологическая и хозяйственная оценка исследуемых сортов винограда

Table 1. Comparative biological and economic appraisal of the studied grapevine cultivars

\begin{tabular}{|c|c|c|c|c|c|}
\hline Сорт & $\begin{array}{l}\text { Гроздей н } \\
\text { куст, шт. }\end{array}$ & $\begin{array}{l}\text { а Масса } \\
\text { грозАи, г }\end{array}$ & $\begin{array}{l}\text { Урожай с } \\
\text { куста,кг }\end{array}$ & $\begin{array}{l}\text { Урожай- } \\
\text { ность, т/га }\end{array}$ & $\begin{array}{l}\text { Прибав- } \\
\text { ка, } \pm \%\end{array}$ \\
\hline Екатеринодарский (к) & 33 & 198 & 6,53 & 10,89 & - \\
\hline Анри К & 34 & 224 & 7,62 & 12,70 & $+16,6$ \\
\hline Йоханнитер & 33 & 203 & 6,70 & 11,17 & $+2,6$ \\
\hline Сенной К & 25 & 257 & 6,49 & 10,82 & $-0,6$ \\
\hline Солярис & 25 & 231 & 5,78 & 9,64 & $-11,5$ \\
\hline
\end{tabular}

масса гроздей превышаца таковую у контроцьного сорта Екатеринодарский на 13,1 \% у кмона Анри К, на 16,7 \% у сорта Сомярис и на 29,8 \% у кмона Сенно К. У сорта Йоханнитер среАняя масса грозди равнялась контрольным показателям.

Наиболее высокий урожай с куста и с гектара получен на кмоне Анри К 12,70 т/га, прибавка урожая по сравнению с контролем составима 16,6 \% (табл. 1). Сорт Йоханнитер и клон Сенной К по урожайности соответствоваци контромю, а сорт Сомярис уступим контролю 11,5\%.

Изучаемые сорта и кмоны по качеству урожая соответствоваци кондициям, предъявцяемым к винограду, идущему на производство сухих виноматериалов. Максимацьная сахаристость отмечалась у сорта Сомярис и кмона Сенной К - 23,4 и 23,5 г/ $\mathrm{cm}^{3}$, соответственно. А самая низкая сахаристость зафиксирова-

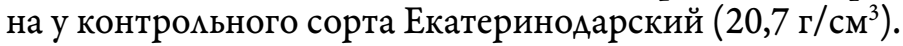

Вина, приготовленные из всех изучаемых сортов и клонов винограАа, получили Аегустационную оценку выше, чем вино, приготовценное из стандартного сорта Екатеринодарский. Максимацьные органолептические результаты отмечались у сорта Сомярис и кмона Сенной К - 8,0 бамла. Сорт Йоханитер и кмон Анри К также превзошии контрольный сорт Екатеринодарский (7,9 против 7,8 бамма).

Согласно комплексной оценке, изучаемые сорта и кмоны винограда расположились в следующем порядке:

Екатеринодарский $\rightarrow$ Йоханитер $\rightarrow$ Анри $\mathrm{K} \rightarrow$ Сомярис $\rightarrow$ Сенно К (табц. 2).

Наиболее эффективно возделывание кмона Анри К. Уровень его рентабельности выше стандартного сорта ЕкатериноАарский на 11,6 процентных пункта. Сорт Йоханнитер и клон Сенной К по экономическим показатемям находятся на уровне стандартного сорта Екатеринодарский, а сорт Соцярис уступает контромю.

Таким образом, новые интродуцированные сорта и созАан-

Таблица 2. Ранжирование признаков сортов винограда и их комплексная оценка.

Table 2. Traits ranking and complex assessment of grapevine cultivars

\begin{tabular}{|c|c|c|c|c|c|}
\hline Показатемь & $\begin{array}{l}\text { Екатерино- } \\
\text { Аарский (к) }\end{array}$ & $\begin{array}{l}\text { Анри } \\
\text { К }\end{array}$ & $\begin{array}{l}\text { Йохан- } \\
\text { нитер }\end{array}$ & $\begin{array}{l}\text { Сенной } \\
\text { К }\end{array}$ & Солярис \\
\hline Урожайность, ц/га & 3 & 5 & 3 & 3 & 1 \\
\hline $\begin{array}{l}\text { Массовая концентрация са- } \\
\text { харов в соке ягоА, г/100 } \mathrm{cm}^{3}\end{array}$ & 1 & 2,5 & 2,5 & 4,5 & 4,5 \\
\hline $\begin{array}{l}\text { Массовая концентрация ти- } \\
\text { труемых кислот, г/Ам }\end{array}$ & 1 & 2,5 & 2,5 & 4,5 & 4,5 \\
\hline Масса грозди, г & 1 & 3 & 2 & 5 & 4 \\
\hline Аата сбора урожая & 1 & 4,5 & 4,5 & 2,5 & 2,5 \\
\hline Аегустационная оценка, бам & 1 & 2,5 & 2,5 & 4,5 & 4,5 \\
\hline Сумма рангов & 8 & 20 & 17 & 24 & 21 \\
\hline
\end{tabular}


ные на их основе кмоны винограда, выделившиеся по признаку стабимьной и высокой урожайности (Анри К и Йоханнитер), а также высокого качества (Сенной К и Сомярис), возможно рекомендовать Аця промышменного возделывания на виноградниках Анапо-Таманской зоны Краснодарского края.

\section{Источники финансирования}

Не указаны.

Financing source Not specified.

\section{Конфликт интересов} Не заявлен

\section{Conflict of interests} Not declared.

\section{Список литературы / References}

1. Айба, В.Ш. Генофонд аборигенных сортов и интродуцентов винограда в Абхазии / В.Ш. Айба, Л.П. Трошин, Р.В.Кравченко // Политематический сетевой электронный научный журнал Кубанского государственного аграрного университета (Научный журнал КубГАУ) [Электронный ресурс]. - Краснодар: КубГАУ, 2014, № 100, C. 831-842.

Ajba, V.Sh., Troshin L.P., Kravchenko R.V. Genofond aborigennyb sortov i introducentov vinograda $v$ Abhazii [Gene pool of aboriginal varieties and introducents of grapes in Abkhazia] // Politematicheskij setevoj elektronnyj nauchnyj zhurnal Kubanskogo gosudarstvennogo agrarnogo universiteta (Nauchnyj zhurnal KubGAU) [Elektronnyj resurs]. [Polythematic network electronic scientific journal of the Kuban State Agrarian University (Scientific journal of KubGAU) [Electronic resource]. Krasnodar, 2014, № 100, C. 831-842. (in Russian)

2. Айба, В.Ш. Изучение аборигенных сортов винограда Абхазии / В.Ш. Айба, Л.П. Трошин, Р.В.Кравченко // Политематический сетевой электронный научный журнал Кубанского государственного аграрного университета (Научный журнал КубГАУ) [Электронный ресурс]. - Краснодар: КубГАУ, 2014. - № 104. - С. 1-23.

Ajba, V.Sh., Troshin L. P., Kravchenko R.V. Izuchenie aborigennyb sortov vinograda Abhazii [Studying Abkhazia's indigenous grape varieties] // Politematicheskij setevoj elektronnyj nauchnyj zhurnal Kubanskogo gosudarstvennogo agrarnogo universiteta (Nauchnyj zhurnal KubGAU) [Elektronnyj resurs]. [Polythematic network electronic scientific journal of the Kuban State Agrarian University (Scientific journal of KubGAU) [Electronic resource], Krasnodar, 2014, № 104, P. 1-23. (in Russian)

3. Гугучкина, Т.И. Перспективы использования новых технических белых сортов винограда, произрастающих в центральной зоне Краснодарского края / Т. И. Гугучкина, О. Н. Шелудько, Н. Н. Бареева, Л. П. Трошин // Новации и эффективность производственных процессов в виноградарстве и виноделии. - Краснодар, 2005. - Т. II. Виноделие. - C. 52-58.

Guguchkina T.I., Shelud'ko O.N., Bareeva N.N., Troshin L.P. Perspektivy ispol'zovaniya nouyb tekbnicheskih belyh sortov vinograda, pro $\rightarrow$ izrastayushchib v central'noj zone Krasnodarskogo krava [Prospects for the use of new technical white grapes grown in the central zone of the Krasnodar Krai] // Novacii i effektionost' proizvodstven $\neg$ nyh processov v vinogradarstve $i$ vinodelii. T. II. Vinodelie. [Innovations and efficiency of production processes in viticulture and winemaking], 2005, P.52-58. (in Russian)

4. Егоров, Е.А. Виноградарство России: настоящее и будущее / Е. А. Егоров, А. Аджиев., К. А. Серпуховитина, Л. П. Трошин и др. Издательский дом «Новый день», Махачкала, 2004. - 438 с.

Egorov E.A., Adzhiev A., Serpuhovitina K. A., Troshin L.P. i dr. Vinogradarstvo Rossii: nastoyashchee $i$ budushchee [Viticulture of Russia: Present and Future]. Izdatel'skij dom "Novyj den'", Mabachkala, Makhachkala, 2004. 438 p. (in Russian)

5. Зубарь, О.М. Ампелографическая оценка белоягодных столовых сортов винограда в условиях Южно-Предгорной зоны Краснодарского края / О.М. Зубарь, Р.В. Кравченко // Информация как дви- гатель научного прогресса: Сб.статей по итогам Международной научно-практической конференции (Саратов, 22 января 2018) / в 3 ч. Ч.3 - Стерлитамак: АМИ, 2018. - С. 216-218.

Zubar' O. M., Kravchenko R. V. Ampelograficheskaya ocenka beloyagodnyb stolovyb sortov vinograda $v$ uslovivah YUzhno-Predgornoj zony Krasnodarskogo kraya [Ampelographic assessment of white-table grapes in the conditions of the South Piedmont zone of the Krasnodar Krai]. // Informaciya kak dvigatel' nauchnogo progressa: sbornik statej po itogam Mezhdunarodnoj nauchno-prakticheskoj konferencii (Saratov, 22 yanvarya 2018) / v 3 ch. CH.3 [Information as a tool for scientific progress: a collection of articles on the results of the International Scientific and Practical conference (Saratov, January 22, 2018) / in 3 hours. Part 3 - Sterlitamak: AMI, 2018. pp. 216-218. (in Russian)

6. Кравченко, Р.В. Сортоизучение перспективных темноягодных столовых сортов винограда в условиях Южно-предгорной зоны краснодарского края / Р. В. Кравченко, С. П. Алексеенко // Colloquium-journal, - 2018. - № 5-2 (16). - C. - 15-16.

Kravchenko R. V., Alekseenko S. P. Sortoizuchenie perspektivnyb temnoyagodnyb stolouyh sortov vinograda v usloviyah yuzhno-predgornoj zony krasnodarskogo kraya [Varietal study of promising darkgrape table grapes in the conditions of the southern-foothill zone of the Krasnodar Krai]. Colloquium-journal, 2018. № 5-2 (16). Pp. 15-16. (in Russian)

7. Матузок, Н.В. Экологически чистая виноградно-винодельческая продукция: новый подход ее получения / Н. В. Матузок, П. П. Радчевский, Р. В. Кравченко, Л. П. Трошин // Труды КубГАУ, 2015. - № 55. - C. 149-155.

Matuzok N.V., Radchevskij P. P., Kravchenko R. V., Troshin L. P. . Ekologicheski chistava vinogradno-vinodel'cheskava produkciya: novyj podhod ee polucheniya [Environmentally friendly wine and wine products: a new approach to obtain it] Trudy KubGAU [Works of KubSAU, Krasnodar, 2015. № 55. pp. 149-155. (in Russian)

8. Матузок, Н.В. Сравнительная агробиологическая и хозяйственная оценка технических сортов винограда для производства сухих вин в условиях Крымского района Краснодарского края / Н. В. Матузок, Л. П. Трошин, Р. В. Кравченко, П. П. Радчевский // Магарач. Виноградарство и виноделие. - Ялта, 2017. - №.4. - С.14-16.

Matuzok N.V., Troshin L.P., Kravchenko R.V., Radchevskij P.P. Sraunitel'naya agrobiologicheskaya $i$ bozyajstvennaya ocenka tekhnicheskih sortov vinograda dlya proizvodstva subih vin $v$ usloviyah Krymskogo rajona Krasnodarskogo kraya [Comparative agrobiological and economic evaluation of technical grape varieties for the production of dry wines under the conditions of the Crimean region of the Krasnodar Krai] Magarach. Vinogradarstvo $i$ vinodelie. [Magarach. Viticulture and winemaking]. Yalta, 2017. № 4. pp.14-16. (in Russian)

9. Радчевский, П.П. Повышение продуктивности технических сортов винограда на основе использования современных технологий / П.П. Радчевский, Н.В. Матузок, Р.В. Кравченко, Л.П. Трошин, Д.В. Сидоренко, И.А. Чурсин // Труды КубГАУ, 2015.- № 55.- С. 223-228.

Radchevskij P.P., Matuzok N. V., Kravchenko R.V., Troshin L.P., Sidorenko D. V., CHursin I. A. Povyshenie produktivnosti tekbnicheskib sortov vinograda na osnove ispol'zovaniya souremennyb tekbnologij [Increasing the productivity of technical grape varieties using modern technologies] Trudy KubGAU [Proceedings of the Kuban State Agrarian University] Krasnodar, 2015. № 55. P. 223-228. (in Russian)

10. Трошин, Л.П. Ампелографическая оценка перспективных розовоягодных сортов винограда в условиях Анапо-Таманской зоны Краснодарского края / Л. П. Трошин,Р. В. Кравченко, Н. В. Матузок П.П . Радчевский, С. М. Горлов, А. В. Милованов, А. С. Звягин // Магарач. Виноградарство и виноделие. - Ялта, 2018. - №.1 $-\mathrm{C} .10-12$

Troshin L.P., Kravchenko R.V., Matuzok N.V., Radchevskij P.P., Gorlov S.M., Milovanov A.V., Zvyagin A.S. Ampelograficheskaya ocenka perspektivnyb rozovoyagodnyb sortov vinograda v usloviyab AnapoTamanskoj zony Krasnodarskogo kraya [Ampelographic assessment of promising pink-berry grapevine varieties under the conditions of the Anapo-Taman zone of the Krasnodar Krai] Magarach. Vinogradarstvo i vinodelie. [Magarach. Viticulture and winemaking]. Yalta, 2018. №.1. pp.10-12. (in Russian) 